This PDF is a selection from a published volume from the National Bureau of Economic Research

Volume Title: Governance, Regulation, and Privatization in the Asia-Pacific Region, NBER East Asia Seminar on Economics, Volume 12

Volume Author/Editor: Takatoshi Ito and Anne O. Krueger, editors

Volume Publisher: University of Chicago Press

Volume ISBN: 0-226-38679-1

Volume URL: http://www.nber.org/books/ito_04-1

Conference Date: June 28-30, 2001

Publication Date: January 2004

Title: The Japanese Experience with Railway Restructuring

Author: Fumitoshi Mizutani, Kiyoshi Nakamura

URL: http://www.nber.org/chapters/c10195 


\title{
The Japanese Experience with Railway Restructuring
}

\author{
Fumitoshi Mizutani and Kiyoshi Nakamura
}

\subsection{Introduction}

Although many countries privatized their railways after 1987 , the privatization of the Japan National Railway (JNR) in that year marked the first sweeping reform of a national railway in the world. Privatization has been accomplished in various ways in different countries. Indeed, railway restructuring in Japan has been markedly different from that in European nations. In this paper, we will explain the Japanese approach to railway reform and discuss the experience gained and lessons learned from the privatization process.

This paper consists of five sections. Section 12.2 summarizes the privatization of the JNR, explaining the impetus for privatization, the steps by which it was achieved, the restructuring options that were available at the time of privatization, and the general characteristics of this privatization. An international comparison is also presented. Section 12.3 describes how the management of the privatized Japan Railways (JRs) differs from that of the former JNR. While most privatization studies focus on regulatory changes, we want to concentrate also on managerial issues such as corporate goals, relationships with interest groups, organizational structure, incentive systems, and task-improving activities. In section 12.4 we show performance results of the regional railway companies after privatization,

Fumitoshi Mizutani is professor of public utility economics in the Graduate School of Business Administration, Kobe University. Kiyoshi Nakamura is professor of industrial economics and associate dean of the School of Commerce, Waseda University.

We would like to thank Mario Lamberte (Philippine Institute for Development Studies), Helen Owens (Productivity Commission, Australia), Takatoshi Ito (University of Tokyo) and the conference participants for valuable suggestions and comments. We also would like to thank an anonymous referee for valuable questions. 
discussing not only overall performance but also rail fare, competition, and the operation of local rail service, and presenting an international comparison of these factors. In section 12.5 we consider several policy issues related to rail restructuring, using as a basis for discussion these topics: regional subdivision, functional division, vertical integration, and yardstick competition. Finally, keeping in mind the situation of developing countries, we outline important points related to rail privatization policy in section 12.6.

\subsection{A Summary of the Privatization of the Japan National Railway}

\subsubsection{The Road to Privatization}

\section{Reasons for Privatization}

Along with two other huge public entities, Nippon Telephone and Telegraph and the Japan Monopoly Public Corporation (Tobacco and Salt), which were privatized in the late 1980s, JNR began the process of privatization in 1987, when it was partitioned into six regional passenger companies (the JRs) and one nationwide freight company.

As a public corporation, the JNR encountered numerous organizational problems, including complacency due to a lack of a sense of crisis, an antagonistic labor-management relationship, and political interference. Reforms were hindered by opposition from politicized labor unions, which were divided into several organizations. The repeated failure of nationalization produced ineffectual alternation between easy dependence on government subsidies and halfway reforms. In 1964, for the first time in its history, JNR showed an operating loss, its competitiveness having been eroded by automation and the failure to reduce its heavy burden of redundant employees. The hostile relationship between management and labor unions profoundly damaged morale in the workplace and lowered productivity and the quality of service.

It gradually became evident to those both inside and outside JNR that divestiture would be necessary to reduce the huge government subsidies supporting JNR, and to enhance its efficiency. The idea that social infrastructure could be paid for not by the government out of strained budgets but with private funding was not new in Japan, since much railway service had been and still is provided by private railway companies. Moreover, since intermodal competition had drastically eroded the domain of JNR as a natural monopoly and the potential for competition in the market was extended, it became obvious that JNR, even though it was such a traditional and politically powerful entity, should be required to work within the framework of a market economy. A divestiture plan was devised by members of a special committee organized by several political entrepreneurs and by proprivatization management inside JNR. 


\section{The Process of Privatization}

One important fact about the JNR privatization was that it was accomplished not all at once, but rather in a step-by-step manner. When railway reform began in 1987, most stock of the newly established JRs continued to be held by the public sector at Japan National Railway Settlement Corporation (JNRSC), a temporary holding company established for this purpose. Stock was not immediately offered to the public, because the government was concerned that the dismal reputation of the deficit-laden and inefficient JNR would affect stock prices negatively, and embarrassingly few investors would be interested in acquiring stock in the new railway companies. It was necessary to sell the stock at as high a price as possible, to help alleviate some of the immense debt bequeathed by the JNR. The newly created JNRSC would hold railway stocks until the newly privatized companies could establish a reputation worthy of a respectable stock offering, by increasing efficiency and showing profits. Thus, although the date of JNR's privatization is given as 1987, strictly speaking the JNR was not privatized that year but rather was launched onto a course toward privatization.

Among the seven JR companies, the most rapidly privatized proved to be JR East, 62.5 percent of whose stock went on the market in 1993. The subsequent recession delayed the issuance of further stock until 1996, when a portion of JR West's shares went on the market, followed by JR Central's shares in 1997. As of 30 June 2002, all of JR East's, 68.3 percent of JR West's, and 60.4 percent of JR Central's shares were held by the private sector. All shares of the other four JR companies, however, are still held by the government, and a specific plan for their issuance has not been determined (Mizutani and Nakamura 2000). By the end of 2002, the privatization of JNR remained incomplete, with the government still holding portions of the JR companies' stock. There is little doubt, however, that the JR West and JR Central railway companies are headed toward full privatization.

\subsubsection{Restructuring Options}

\section{General Important Features of Restructuring}

As Moyer and Thompson (1992) point out, the restructuring of a railway business must focus on key elements that promote the ability of the railway to meet the needs of its potential users: its assets, liabilities, workforce, management style, and business strategy. As case studies in Europe, North America, and Japan indicate, different prototypes of restructuring have been adopted to enhance the competitiveness of railways. The following are major options for asset restructuring of the railway: geographical division, vertical separation, and functional distinction. 
As for geographical division, because of a genetic trait of transport markets, the railway market and physical assets such as the track and terminals can be divided geographically. Geographical market segmentations involve separating freight and passenger markets into several subnetworks. In general, traffic demands on railways are mainly local, or concentrated on specific segments of the networks, so that geographical segmentation may be better suited to offering services to meet local needs.

As for vertical separation, as in telecommunications and other public utilities, the railway business constitutes (1) naturally monopolistic elements, such as track maintenance, and (2) potentially competitive elements, such as train operations and commercial functions. Unbundling track maintenance (the lower part of railways) from train operations (the upper part of railways), at least in theory, is considered one way to sharpen the competitive edge of railways in the transport market. However, as the case of British Rail indicates, the division of track from trains becomes problematic because an adversarial relationship has developed between the central track authorities and the train-operating companies. Problems associated with vertical separation include high transaction costs, a need for monitoring of the other's performance, the difficulty in creating complex performance schedules, and the stimulation of incentives for the track authority to invest in new facilities to increase efficiency and improve safety.

In terms of functional distinctions, railways basically serve two important markets - passenger and freight — each with its own operational and geographical uniqueness. A distinction between passenger and freight markets is logical, because it would make the railway companies more responsive to specific needs of particular users. However, if economies of scope between the related activities are known to be significant, then a horizontal distinction policy is not the best choice.

As far as asset reorganization for debt reduction is concerned, the various mechanisms include selling nonessential assets by auction, offering to the public stock and land (including terminals), franchising or leasing, or selling operating rights.

\section{The Japanese Approach to Restructuring}

What would be the best general practice for restructuring any railway? Specific options are most suitable for achieving specific results. Later we will discuss what options other nations have chosen in the restructuring of their railways. In the case of Japan, because of the highly dense population along the major railway lines and the extremely strong commuter demand in metropolitan areas, vertical integration and geographical separation may be the best choices for restructuring. Large economies of scope seem to exist not only between related activities but also between railway and nonrailway activities, including residential development along the lines, 
tourism, retailing, and so forth. The question of which policies should be applied is perhaps most important for enhancing the efficiency and competitiveness of railways, but there is no clear general answer to this question. One critical question seems to be how structural reforms could include incentive mechanisms, because the structural policy of a railway should go hand in hand with competitive measures for efficiency.

As we discussed in previous work, the Japanese approach to railway privatization has six distinguishing features: (1) horizontal separation (or regional subdivision), (2) functional distinction (or passenger-freight distinction), (3) vertical integration (or operation and infrastructure integration), (4) lump-sum subsidies for low-density JRs, (5) the establishment of an intermediary institution, and (6) allowance of nonrail service (Mizutani and Nakamura 1997). With this study, we add to the list a new distinguishing feature: (7) the yardstick competition scheme. We will briefly explain these characteristics.

The main problem with JNR was that it was too large an organization to be managed properly and it was expected to operate even unprofitable lines built only because of political influence. Thus it was decided that the company would be separated into six regional passenger railway companies, and each company would gain control over decisions about which lines to operate and which lines to close. After consideration of several options for separation, regional subdivision by geographical demand was decided upon. The smaller, subdivided companies would be expected to meet their users' local needs, and to compete with each other to improve their performance. In this subdivision, 95 percent of all trips would be completed within the borders of these regions. In addition to two distinct regional JRs - JR East and JR West in the Tokyo and Osaka metropolitan areas, respectively - JR Central, based in Nagoya, was appointed to be the operator of the most profitable trunk-line, Shinkansen, between Tokyo and Osaka.

Second, because of the growth of the trucking industry, whose increasing success had caused a severe decline in the share of rail freight business, it was decided to separate JR Freight from the passenger JRs. Were JR Freight to remain within the fold of the passenger JRs, it was feared that managerial responsibility for its losses would be vague and its poor performance would damage the morale and the good results the healthier passenger companies were bound to achieve. To avoid an excessive financial burden on JR Freight, however, it would be allowed to borrow tracks from infrastructure-holding passenger JRs, instead of holding the infrastructure itself. Regional separation was not chosen, in order to retain scale merit.

Third, unlike in the European rail industry and in marked contrast to the privatization of British Rail, vertical integration was maintained after privatization. In theory, it was possible to introduce vertical separation of 
track ownership and rail operation, but this was not seriously discussed before privatization (Suga 1997). Most railways in Japan are privately owned, integrated systems, and their success most likely made vertical separation seem an unattractive and excessively complicated option. Furthermore, since major urban private railways have been increasing profits by diversifying into various businesses - such as running department stores and hotels at stations, developing residential land along the tracks, and promoting tourism - privatized JRs were expected to behave likewise, making the integration of track ownership and train operation desirable in light of the possibility for diversification.

Fourth, in order to stabilize the management situation for smaller JRs, a lump-sum subsidy scheme was implemented through the Management Stabilization Fund (MSF), with interest revenues from the fund to cover these subsidies. Since the three-islands JRs were handicapped by geographical locations with relatively small populations and the rapid development in their regions of highway networks, lump-sum funds $(1,278$ billion yen) were channeled to these JRs. The fund, which originally took the form of a ten-year debt owned by the JNRSC, was supposed to yield interest and subsidize the operating losses of these JRs. However, the market interest rate decreased so that the interest revenues could not cover the operating deficits of the three-islands JRs. Therefore, a new scheme was implemented in 1997 whereby the Corporation for Advanced Transport and Technology (CATT) borrowed portions of the MSF funds of the threeislands JRs at a fixed interest rate of 4.99 percent, higher than the market rate. Scheduled to be eliminated by the end of fiscal year 2001, this scheme was extended to fiscal year 2006. Without the MSF these JRs will go in the red, making them unattractive candidates for listing on the stock market, so they have postponed plans for issuing their stock.

Fifth, JNRSC was set up as an intermediate institution to repay the debts of the JNR and to find new jobs for its redundant employees. The Japanese government and JNR management placed top priority on facilitating the transfer of dismissed employees to other sectors by enacting a special law for reemployment of former JNR workers in the process of privatization. As a result, in contrast to privatization practices elsewhere in the world, little labor rationalization was undertaken. To avoid sweeping layoffs, every imaginable means of reducing unemployment and social conflict was introduced, including transfers to local governments, public organizations such as the National Tax Administration Agency, the Police Agency, the Meteorological Agency, and the flourishing Nippon Telephone and Telegraph as well. Moreover, the JNRSC was established to transfer these redundant workers smoothly to other sectors. With generous inducements for voluntary retirement, reduction in the workforce had begun well before the implementation of privatization, so that only 1,047 remained to be dismissed in the process of privatization. 
Sixth, JRs have been allowed to engage in nonrail business, as private rail companies have been doing in Japan for decades. To increase demand for rail transportation, private rail companies conduct such businesses as housing development, tourism, and the operation of other modes of transport such as buses. The JR companies have begun to follow the example of these private railways and tried their luck in various non-rail-related enterprises.

Finally, a yardstick competition scheme was introduced. Under this scheme, rail operators compete with each other to improve performance, and the regulator assesses the operators' performance by using common measures. The results of this assessment are to be used when fare revision is being considered.

\section{Regulatory Changes and Ongoing Plans}

Table 12.1 shows regulatory changes and ongoing plans since privatization. First, the organizational form was converted from a public corpora-

Table 12.1

Major Regulatory Changes with Privatization, and Desired Results

\begin{tabular}{|c|c|c|c|}
\hline & Before Privatization & After Privatization & Desired Result \\
\hline Organization & Public corporation & Special corporations & $\begin{array}{l}\text { Genuinely private com- } \\
\text { panies }\end{array}$ \\
\hline Operations & Nationwide service & $\begin{array}{l}\text { Six regional passenger } \\
\text { companies and one } \\
\text { freight company for all } \\
\text { Japan }\end{array}$ & No change \\
\hline Rail services & $\begin{array}{l}\text { Integrated services of } \\
\text { passenger and freight }\end{array}$ & $\begin{array}{l}\text { Separation of passenger } \\
\text { and freight services }\end{array}$ & $\begin{array}{l}\text { No change, but possibly } \\
\text { reorganization of the } \\
\text { freight company }\end{array}$ \\
\hline $\begin{array}{l}\text { Scope of } \\
\text { business }\end{array}$ & $\begin{array}{l}\text { Rail-related services } \\
\text { only }\end{array}$ & $\begin{array}{l}\text { Nonrail businesses (e.g., } \\
\text { residential development, } \\
\text { tourism) allowed }\end{array}$ & $\begin{array}{l}\text { More diversification of } \\
\text { businesses }\end{array}$ \\
\hline $\begin{array}{l}\text { Approval of } \\
\text { fare }\end{array}$ & Approval by the Diet & $\begin{array}{l}\text { Approval by the } \\
\text { Transport Minister }\end{array}$ & $\begin{array}{l}\text { Notification to Ministry } \\
\text { of Land, Infrastructure, } \\
\text { and Transport }\end{array}$ \\
\hline $\begin{array}{l}\text { Fare } \\
\text { regulation }\end{array}$ & $\begin{array}{l}\text { Strict control by the } \\
\text { government }\end{array}$ & $\begin{array}{l}\text { Strict control by the } \\
\text { government; installation } \\
\text { of yardstick competition } \\
\text { scheme in January } 1997\end{array}$ & $\begin{array}{l}\text { Incentive regulations } \\
\text { such as price caps }\end{array}$ \\
\hline $\begin{array}{l}\text { Investment and } \\
\text { financing }\end{array}$ & $\begin{array}{l}\text { Capital supplied by the } \\
\text { government and invest- } \\
\text { ment plan requiring } \\
\text { Diet approval }\end{array}$ & $\begin{array}{l}\text { Japan Railway companies } \\
\text { allowed to invest without } \\
\text { Diet approval but minis- } \\
\text { terial approval required }\end{array}$ & $\begin{array}{l}\text { No ministerial approval } \\
\text { needed on important } \\
\text { business matters, } \\
\text { including the appoint- } \\
\text { ment of top executives, } \\
\text { bond issuance, and } \\
\text { borrowing }\end{array}$ \\
\hline
\end{tabular}


tion, which was one government body, to a special corporation in a stockcompany-style commercial body, still regulated by special laws (Mizutani 1999b). These are expected to become fully private corporations, and the special laws related to them are to be abolished.

Second, operations and rail services were divided into six regional passenger companies and one nationwide freight rail company. So far, there are no specific further plans, but freight rail services might be reorganized because of recent concerns about environmental issues and competition with trucks.

Third, as for scope of business, as we mentioned above, JRs have been allowed to be involved in nonrail business since privatization, and these activities continue to expand, with the aim of securing rail ridership and fully utilizing internal resources.

As for fare approval and fare regulation, governmental intervention has been lighter after privatization. Before privatization, rail fare was approved by the Diet but is now regulated by the Transport Ministry, which is still ultimately a division of the national government. However, yardstick regulation has been introduced as an incentive scheme, and quite recently officials have begun to consider a price-cap scheme for determining rail fare.

Since privatization, the government has intervened less in matters of investment and financing, as well as in other areas of corporate management, such as the appointment of directors. Special laws and regulations have been enacted, including guarantees of a certain degree of autonomy in the JRs' management. This contrasts with the situation that existed in the JNR era when there was a great deal of pressure from and tinkering by politicians; their intervention had deleterious effects on the efficiency of JNR management. The full privatization expected to be realized eventually at all the JRs will afford their managers even more freedom to conduct their business as they see fit.

\section{JNR Debts and the JNR Settlement Corporation}

The transfer of 37.1 trillion yen of liabilities was supervised by the JNRSC, which itself took on about 60 percent of the total debt and was expected to liquidate this liability by selling JNR-owned real estate ( 7.7 trillion yen) and stocks (1.2 trillion yen). The remaining 40 percent of the long-term debt was allocated to the three main-island passenger JRs. The three small-island JRs were exempted from liability because their profitability was very uncertain, given the small size of their markets and lower population density. Originally, it was expected that the taxpayer bear the burden of the more than 13.8 trillion yen debt. The JNRSC has sold 6.22 million shares of the three main-island JRs' stock, out of a total of 9.19 million shares. The corporation has paid back 2.7 trillion yen. However, due to the delay in sales of stock and land after the collapse of the asset-inflated bubble economy in the early 1990s, the JNRSC's liabilities have been in- 
creasing because of staggering interest payments of about 1 trillion yen annually.

Although the JNRSC was reorganized as a division of the Japan Railway Construction Public Corporation (JRCC) and named the Japan Settlement Headquarters in 1998, there has been no change in the longterm debt issue. In spite of the current plan of JRCC to pay back 3.9 trillion yen by selling JR stocks and land, taxpayers will have to shoulder the 24.1 trillion yen loan, which is to be repaid from the general-account budget over the next sixty years.

\section{The Shinkansen Holding Company}

The Shinkansen Holding Company was organized to own and lease infrastructure properties of the Shinkansen and to allocate the resulting profits to the three main-island JRs. It was disbanded because the leasing system would be problematic when Shinkansen assets would be disposed of at the end of the leasing period. The Shinkansen assets were sold to the three main-island JRs through an installment plan, further increasing these JRs' long-term debt. The resulting problem was so severe that even JR Central, although it owns the most profitable Shinkansen line between Tokyo and Osaka, must make annual interest payments worth one-quarter of its yearly earnings.

\subsubsection{An International Comparison of Rail Restructuring}

For comparative purposes, we consider examples of reform of national railways in three European nations: France, Sweden, and the United Kingdom. Table 12.2 summarizes the main features of the restructuring of these nations' railways.

While the Japanese chose a vertically integrated structure, vertical separation seems more common in Europe, although the adoption schedule differs from country to country. Sweden took a separation policy early on, while France did so more recently, according to the Europe Conference of Ministers of Transport ([ECMT] 1998). Second, ownership of established rail companies is different among countries, with the most radical change occurring in the United Kingdom, where newly established train operating companies (TOCs) and the infrastructure provider Railtrack are all joint stock companies. JR companies also are intended to be joint stock companies, but their evolvement into such is ongoing and less drastic than in the case of the British Rail. In both France and Sweden, state railway companies are still owned by the public sector, although rail operations are provided on a commercial basis.

Presumably, decisions related to structure and ownership reflect the general opinion of a nation as to how involved the public sector should be in the rail industry. In France and Sweden, state influence on investment decisions is still higher than in the United Kingdom. In Japan, while the JNR 


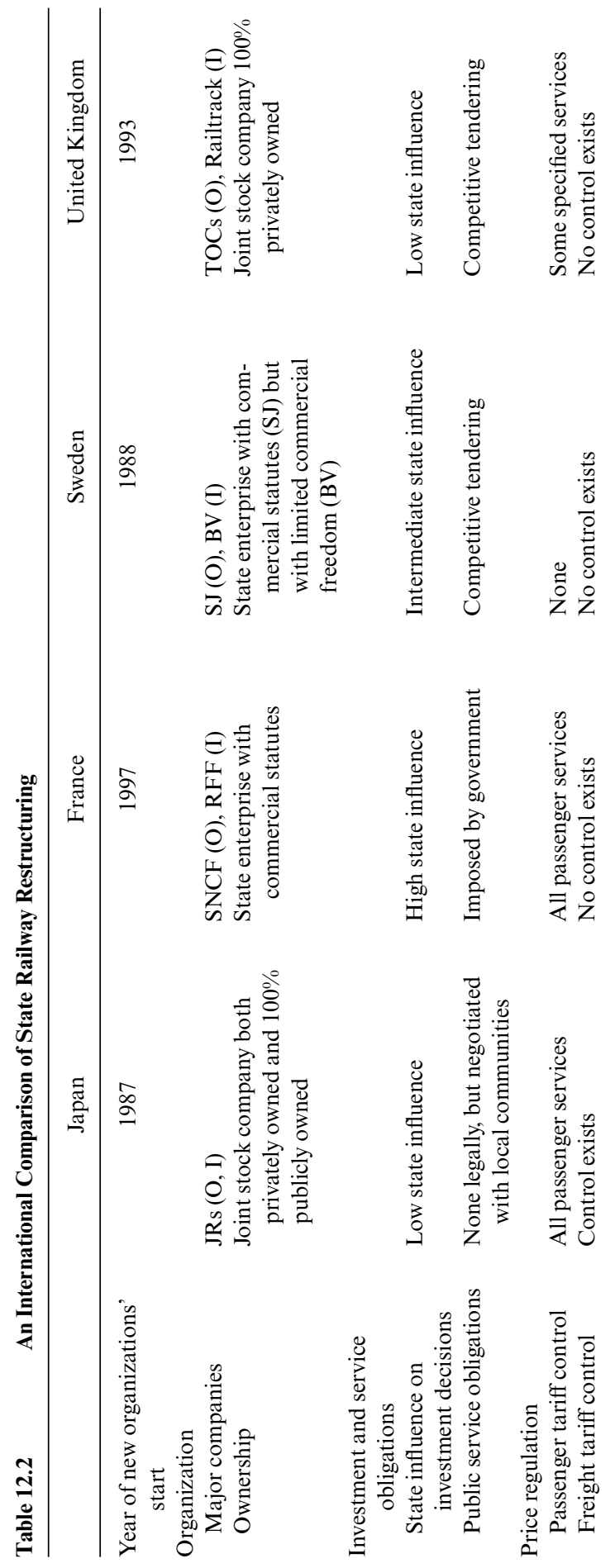




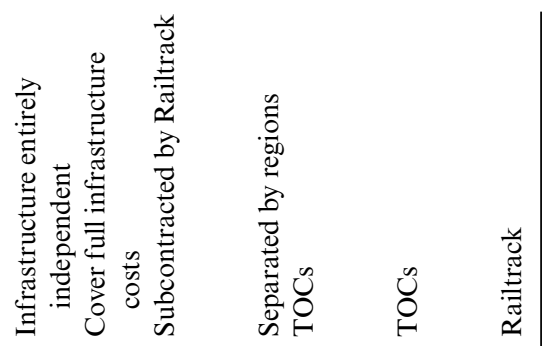

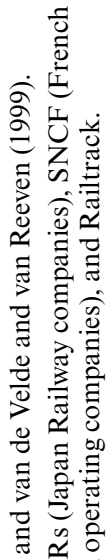

倦 总

节泀

焉

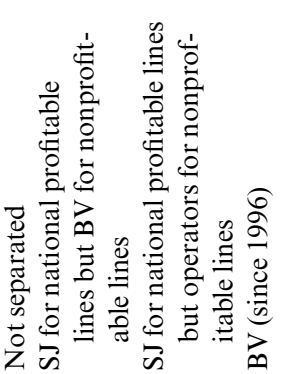

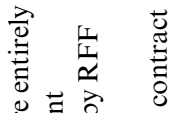

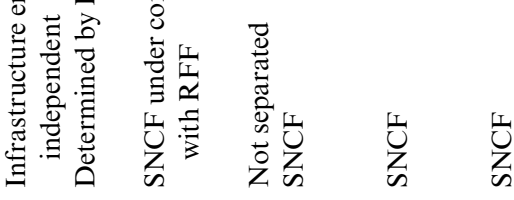

๙

สิ

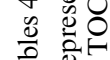

च

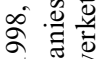

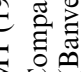

ن

$\exists$

过 范

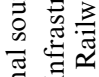

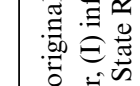

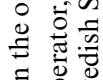

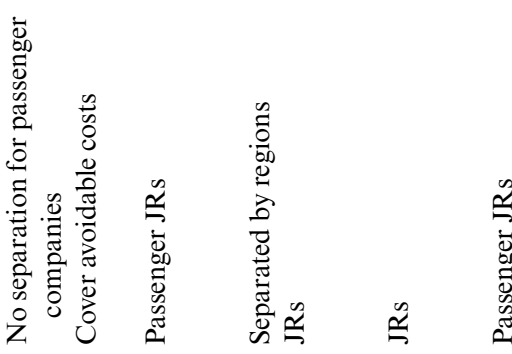

ธี оัँ

迥包

产

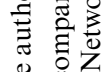

Ð

글

吾 웡

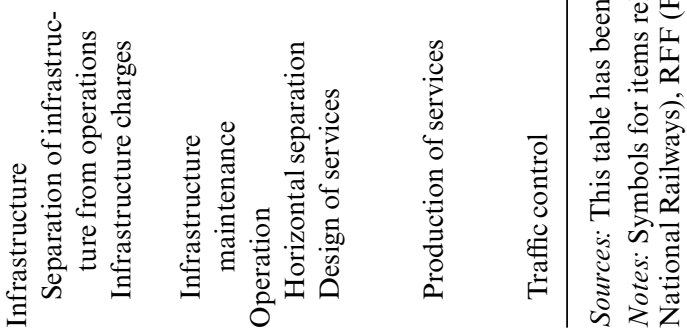


was interfered with rather heavily by the government, the JRs are relatively free of political interference. As for service obligations to the public, European railways clearly are obliged to maintain service, with services in the United Kingdom and Sweden being decided by competitive tendering. In Japan there is no legal obligation to maintain local services, but depopulated communities often negotiate with JR companies regarding the maintenance of local lines and other matters related to local service. This results in what might be called a type of unofficial social contract between the rail companies and local communities.

Finally, as for rail service operation, horizontal separation was selected in Japan and the United Kingdom, while state railway companies have taken over most services in France and Sweden. Of the four railways under observation here, the United Kingdom's system seems to have undergone the most drastic change, with each regional operating company selected by competitive tendering. In Japan, each regional JR company is given a rail license outright, so that there is no need to compete for infrastructure.

\subsection{Managerial Reforms at JR}

\subsubsection{Management Goals}

Sumita (2000) argued from his experience that in state-owned corporations, management responsibility is not clarified, so even if performance targets are not met, there is no need to assume responsibility as long as the best possible efforts have been exerted. One important problem of the JNR was the intervention of many stakeholders: politicians, government officials, unions, and rail users. Intervention from these groups could not be avoided, resulting in a complete loss of independence for JNR. For example, government officials and managers of JNR wishing to manage it more efficiently might deem it necessary to reduce wages and increase fares, while unions and rail users might find these actions unacceptable and put pressure on the government not to change. Conflicting interests led to vague "solutions," and the goals of the JNR became unclear; in fact, its performance goals were drawn up solely for the sake of convenience, in order to have pertinent laws or the budget passed by the Diet. After privatization, the goals of the JRs became clearer.

\subsubsection{Relationships with Interest Groups}

Massive strikes by labor unions often occurred at the end of the JNR era, and the relationship between management and labor unions was at its worst (Mizutani 1999a). Since then, the situation has improved, mainly because management and labor unions seem to be working toward the same goals, with management now giving rewards in the form of salary increases 
when performance has improved. This, in turn, seems to lead to further improvement and an increased sense of trust.

It is not clear how relationships with the local community have changed since privatization, but it is certain that before privatization they were not good. Sumita (2000) suggests that the local community was a rather spoiled interest group using private automobiles to distribute petitions demanding extra services from the JNR and protesting loudly when lossmaking lines were slated for elimination. A cooperative relationship between communities and the JNR was made difficult mostly because local autonomous municipalities were forbidden by law to furnish subsidies to JNR. In the process of privatization, many local lines were converted to bus services or other rail companies which were owned by both the private and public sectors. As we will explain later, there is still the possibility of future conflict between the two groups with regard to maintaining local service in small communities.

\subsubsection{Organizational Structure}

Newly established JRs have assumed a structural form designed to facilitate decision making. JNR had been an unwieldy and bureaucratic organization, unresponsive to external change. It was clearly too large to be a single organization and too centralized for efficient decision making. As a result, there were several problems, such as the excessive length of time it took to make a decision and the inability of the organization to meet local needs quickly. To approve a single initiative, it was necessary to circulate documents among twenty to thirty people who would stamp them with their personal seals (Ishi, Okada, and Yada 1994). JNR's reform therefore stipulated not only privatization but also regional subdivision into organizations smaller than JNR. Moreover, the JRs themselves became less centralized organizations in general. For example, branch offices now have more freedom to use their own judgment when making a decision.

Public enterprises lack the will to economize on construction costs or general expenses because generating earnings is not necessarily the first priority of the operation, at least not in Japan. Once agreed upon, budgets, whether at a state or local government level, must be spent in their entirety, and those making efforts to economize and save portions of the budget are regarded as naive. Therefore, almost no efforts are made in these entities to reduce expenditures, and corporate performance is generally poor. On the other hand, private enterprises must generate earnings, or failures would make it impossible to survive in a market where competition from the automobile and airline industries is a constant threat.

As for organizational structure, two kinds of reforms are important: the change to a flat organization and the introduction of an M-form type of structure. First, like most government entities, the JNR was a typical hierarchy with a vertical organization. Government ministries in the past have 
often been seen as examples of dysfunctional vertical organizations where individual bureaus operated separately but the ministries as a whole failed to function as coordinated units (Sumita 2000). In order to improve upon this kind of organization, first, hierarchy became more flat, evolving from four stages-(1) division manager, (2) section manager, (3) section vicemanager, and (4) subsection - to three stages: (1) division manager, (2) section manager, and (3) subsection. This change shortened decision-making time (Kitani 1997). However, in Mizutani's study (1999a), based on structural maps made available by each JR, the number of divisions increased by about 40 percent from 1987 to 1995 . Furthermore, as for characteristics of structural changes, the Honshu JRs show an increase in management divisions and branch offices while the three-islands JRs show an increase in nonmanagement divisions.

Second, the traditional JNR organization was divided into groups with similar job skills, and the decision making of each division was sometimes superior to the decision making of the entire organization. In other words, the old organizational structure encouraged sectionalism and frequently resulted in divisions' consciously thwarting each other, a serious obstacle to getting the entire organization to achieve its full potential. For example, according to Sumita (2000), JNR's civil engineering group was powerful and there were members of the Diet from this group, so that the civilengineering contingent had a firm hold on a major portion of the budget for many years - a situation that may have accounted for a surfeit of new line construction in the JNR era. To avoid the possibility of a similar problem developing, the M-form type of organization was introduced when the privatization process began. For example, JR East set out to streamline its organization and unify separate departments performing similar work. Sumita reported that integration and unification resulted in information's no longer being restricted to one group exclusive of all others, and in a growing feeling of team spirit throughout the company as a whole.

\subsubsection{Incentive Systems}

A more private, company-style performance rating system was introduced. The wage system at JNR was based mostly on age and seniority, a system with no built-in incentive to improve performance. However, Sumita (2000) noted that when JR East listed its shares on the stock market in 1993, the majority of its employees opted to become shareholders. Partially owning the company where they work has proved to be a major morale and incentive booster for both management and employees.

\subsubsection{Task-Improving Activities}

As for task improvement, activities such as the quality control (QC) circle, the suggestion system, and other forms of action have been taken at 
the initiative of employees. The QC Circle and the suggestion system are very popular among manufacturing and construction companies in Japan and are used to make clear the task responsibility of each employee. In our experience, we cannot state without reserve that these schemes help improve productivity, but Sumita (2000) reported that more than 5 billion yen per year is being saved through the QC Circle, the suggestion system, and other forms of action taken at the initiative of employees.

\subsection{The Performance of JRs after Privatization}

\subsubsection{Overall Performance Changes}

\section{Comparisons since Privatization}

In this section, we will evaluate the overall performance of JR companies since privatization. For a detailed comparison between before and after privatization, please see our previous research, such as Mizutani and Nakamura (1996, 1997). The overall performance of the six JR companies since privatization is summarized in table 12.3, where we selected nine performance measures and compared three time periods: (1) the beginning of privatization (1987); (2) the fifth year after privatization (1992); and (3) the most recent year (1998). In this analysis, we use as a benchmark the performance results of fifteen large private railways.

Overall performance for most JRs has been improved since privatization. However, compared with the numbers in 1992, the most recent results seem desultory, perhaps due to the recent recession in the Japanese economy. JR Freight's financial performance (operating revenues-cost ratio) was especially dismal, sinking to a level lower than at the beginning of privatization.

Among these measures, efficiency has been much improved since privatization. Certainly, labor productivity has been improving. In our previous study (Mizutani and Nakamura 1996), the JRs' labor productivity after privatization was shown to be still inferior to that of large private railways, but the difference may have disappeared by now. The measure of JR Central was higher than for large private railways in 1998. In fact, when we compared the total productivity growth of JRs with that of private railways, the average annual growth rate of JRs shows much higher values: for $1987-1992$, JR (11.40 percent), private ( -0.70 percent); and for $1993-1998$, ( -0.48 percent), private $(-0.03$ percent $)$. As for the average costs, the level was certainly lower than in 1987. The rate of decrease in average operating cost is higher than that of large private railways. Thus, when we compare the JRs' efficiency measures to those of large private railways, we find that the JRs' measures are improving significantly. 


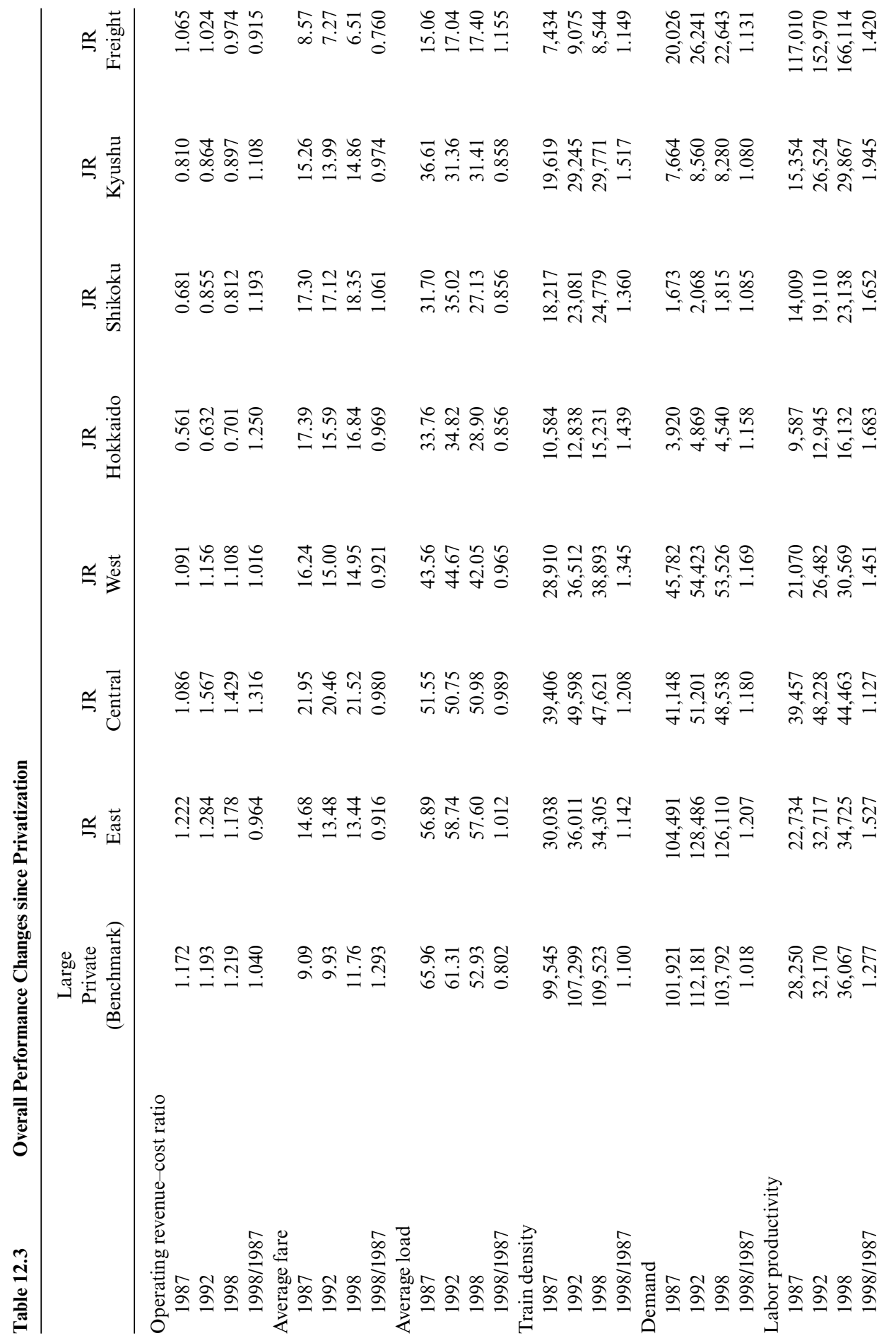




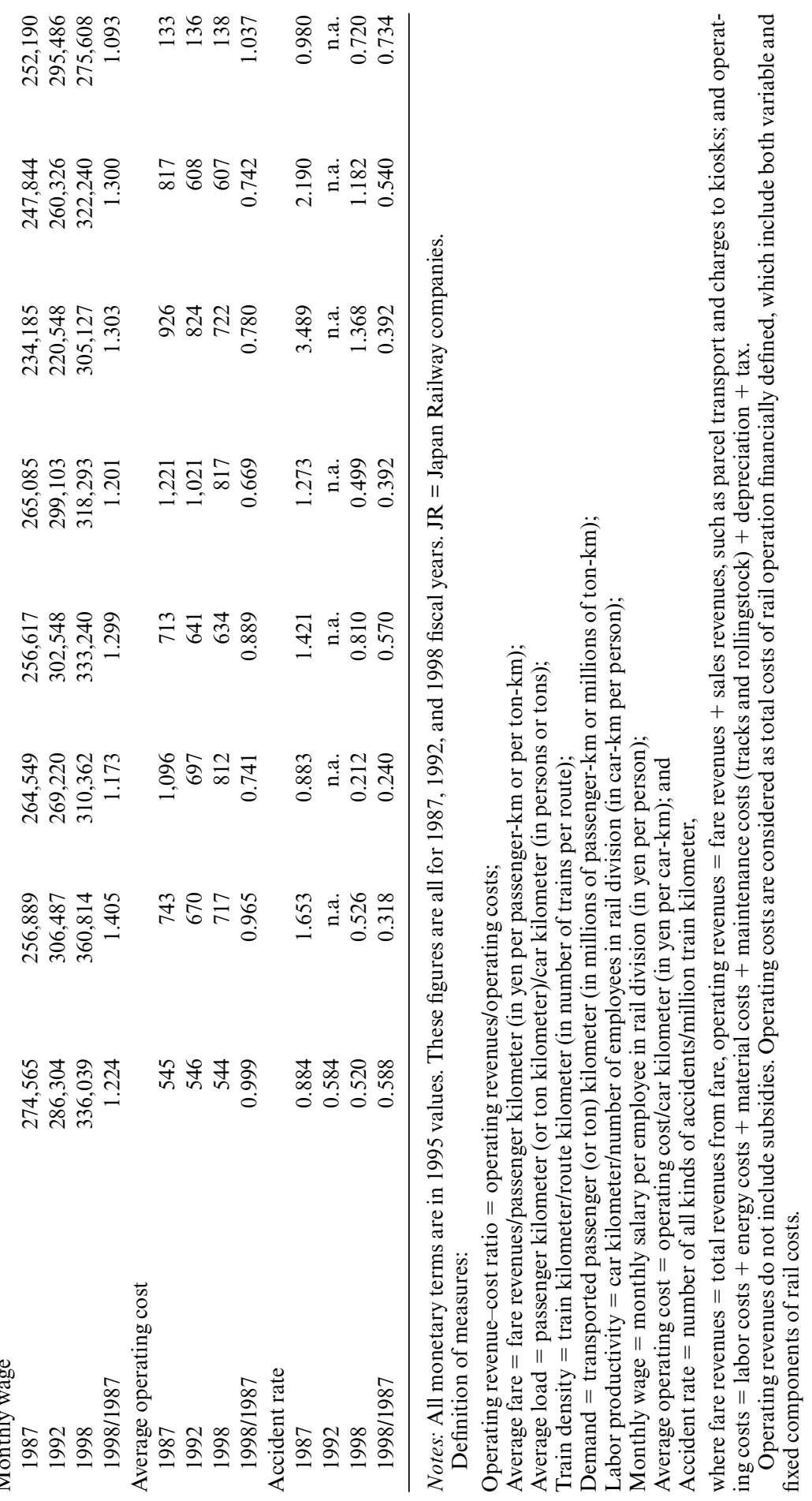




\begin{tabular}{lcc}
\hline Date of Revision & Passenger (\%) & Freight $(\%)$ \\
\hline & Before Privatization & \\
20 April 1981 & 9.7 & 9.7 \\
20 April 1982 & 6.1 & 6.3 \\
20 April 1984 & 8.2 & 4.2 \\
20 April 1985 & 4.4 & 3.1 \\
1 September 1986 & 4.8 & - \\
& After Privatization & 3.0 \\
1 April 1989 & 2.9 & 3.0 \\
10 January 1996 & $7.0^{\mathrm{b}}$ & \\
& $6.7^{\mathrm{c}}$ & 1.9 \\
\hline
\end{tabular}

Source: Ministry of Transport (2000, 115).

${ }^{\mathrm{a}}$ Enacted consumption tax ( 3 percent).

bJR Hokkaido.

'JR Shikoku.

dJR Kyushu.

'Increased consumption tax rate to 5 percent.

\subsubsection{Rail Fare}

\section{Rail Revision}

Rail fare at JNR was expected to cover all rail costs, but was based on the outcome of political deals, not on sound economic judgment. Political interference in rail operation and investment increased rail costs and led to inefficiency, resulting in a fare increase almost every year from 1981 until 1987, when privatization began. Table 12.4 shows the record of fare revision of the JRs, which, other than the three-islands JRs, did not increase fare level during the ten years after privatization, excepting the two years immediately following the introduction of the consumption tax. Maintaining fare at the same level as at the start of privatization indicates that the real value is decreasing, and an increase in ridership can be expected. In fact, Sumita (2000) reports that JR East has made every effort not to increase rail fare. Thus, one important effect of the privatization of JNR was to stop the almost yearly increase in fare.

\section{Parallel Rail Lines}

Rail fare at the JR companies after privatization became more competitive than that of other private rail companies, the most notable case being on JR lines parallel with private rail company lines in large metropolitan areas. Table 12.5 shows a rail fare comparison between JR and large private rail companies along some selected parallel lines. The table shows that in 
Fare Comparison between Japan Railway Companies (JRs) and Major Private Railways of Selected Competitive Lines

\begin{tabular}{|c|c|c|c|c|c|}
\hline \multirow[b]{2}{*}{ Section of a Line } & \multirow[b]{2}{*}{ Operator } & \multicolumn{2}{|c|}{$\begin{array}{l}\text { Regular Fare } \\
\text { (Yen) }\end{array}$} & \multicolumn{2}{|c|}{$\begin{array}{l}\text { Commuter Rail Pass } \\
\text { (Yen per Month) }\end{array}$} \\
\hline & & $01 / 04 / 1986$ & $01 / 10 / 2000$ & $01 / 04 / 1986$ & $01 / 10 / 2000$ \\
\hline \multicolumn{6}{|l|}{ Tokyo } \\
\hline \multirow[t]{3}{*}{ Ueno-Narita } & JR East & 730 & 890 & 21,500 & 26,280 \\
\hline & Keisei & 680 & 810 & 17,400 & 21,920 \\
\hline & $\mathrm{JR} /$ private & 1.07 & 1.10 & 1.24 & 1.20 \\
\hline \multirow[t]{3}{*}{ Shinjuku-Hachioji } & JR East & 440 & 460 & 13,200 & 13,860 \\
\hline & Keio & 290 & 350 & 9,300 & 13,190 \\
\hline & $\mathrm{JR} /$ private & 1.52 & 1.31 & 1.42 & 1.05 \\
\hline \multirow[t]{3}{*}{ Shinagawa-Yokohama } & JR East & 260 & 280 & 7,800 & 8,190 \\
\hline & Keikyu & 230 & 290 & 7,580 & 11,260 \\
\hline & $\mathrm{JR} /$ private & 1.13 & 0.97 & 1.03 & 0.73 \\
\hline \multicolumn{6}{|l|}{ Nagoya } \\
\hline \multirow[t]{3}{*}{ Nagoya-Gifu } & JR Central & 480 & 450 & 12,460 & 13,080 \\
\hline & Meitetsu & 480 & 540 & 12,460 & 16,340 \\
\hline & $\mathrm{JR} /$ private & 1.00 & 0.83 & 1.00 & 0.80 \\
\hline \multirow[t]{3}{*}{ Nagoya-Yokkaichi } & JR Central & 440 & 460 & 13,200 & 13,860 \\
\hline & Kintetsu & 430 & 610 & 11,500 & 19,780 \\
\hline & $\mathrm{JR} /$ private & 1.02 & 0.75 & 1.15 & 0.70 \\
\hline \multicolumn{6}{|l|}{ Osaka } \\
\hline \multirow{3}{*}{$\begin{array}{l}\text { Tennoji (Nanba)- } \\
\text { Wakayama }\end{array}$} & JR West & 730 & 830 & 21,500 & 24,750 \\
\hline & Nankai & 700 & 890 & 15,500 & 25,050 \\
\hline & $\mathrm{JR} /$ private & 1.04 & 0.93 & 1.39 & 0.99 \\
\hline \multirow{3}{*}{$\begin{array}{l}\text { Osaka (Umeda)- } \\
\text { Sannomiya }\end{array}$} & JR West & 380 & 390 & 11,400 & 11,960 \\
\hline & Hankyu & 230 & 310 & 8,780 & 12,480 \\
\hline & $\mathrm{JR} /$ private & 1.65 & 1.26 & 1.30 & 0.96 \\
\hline \multicolumn{6}{|l|}{ Fukuoka } \\
\hline \multirow{3}{*}{$\begin{array}{l}\text { Hakata (Fukuoka)- } \\
\text { Kurume }\end{array}$} & JR Kyushu & 590 & 720 & 16,600 & 20,750 \\
\hline & Nishitetsu & 500 & 600 & 14,850 & 22,280 \\
\hline & $\mathrm{JR} /$ private & 1.18 & 1.20 & 1.12 & 0.93 \\
\hline \multirow{3}{*}{$\begin{array}{l}\text { Hakata (Fukuoka)- } \\
\text { Omuta }\end{array}$} & JR Kyushu & 1,000 & 1,250 & 28,760 & 33,980 \\
\hline & Nishitetsu & 850 & 1,000 & 22,500 & 29,480 \\
\hline & $\mathrm{JR} /$ private & 1.18 & 1.25 & 1.28 & 1.15 \\
\hline
\end{tabular}

Sources: Ministry of Transport (2000, 110-111; 1986, 88-89).

almost all cases the difference in fare level between JRs and large private rail companies became smaller, and in some cases the JRs' fare level became even lower.

The JRs' decreasing relative fare level is certainly due to the increase in productive efficiency caused by the privatization of JNR. Clearly, the unit cost of JR companies has decreased compared with that of JNR, making it a matter of course that JRs' price level has become lower.

Notably, the decrease in JR fare to the level of that of private railways 
was not the same for all lines. In general, cases in the Nagoya and Osaka areas, where there are more parallel lines, showed larger decreases than cases in the Tokyo area. During the JNR era, JNR lines were not considered serious competition for the private railway lines parallel to them, but after privatization, each regional JR company has aimed to make all regional lines more competitive, with a resulting close in the price gap.

\subsubsection{Competition}

One important and distinguishing effect of the privatization of the JNR is that competition has worked actively in many ways. First, the Shinkansen became a viable alternative to the airplane along the major longdistance trunk corridor, with popular routes being Tokyo-Osaka, OsakaFukuoka, Tokyo-Fukuoka, Tokyo-Yamagata, and Tokyo-Akita. The companies focused mainly on shortening transport time, but attention was paid also to service quality and price. For example, JR West has actively introduced new types of rail cars between Osaka and Fukuoka in order to win business trips from air transportation. The new types of cars provide new amenities such as compartment rooms for meetings, electrical outlets for personal computers, and silent cars for passengers who want to rest. Furthermore, travel time has been reduced by more than 20 percent.

In the medium distance, bus transportation might be a competitive mode. For example, direct service from city center to airport could be a typical case of medium-distance bus service. Although there is no statistical evidence, convenient direct bus services are emerging as strong competitors of privatized JR companies.

The privatization of the JNR has affected other transport organizations, attracting business away from them and reducing their ridership. In the greater Osaka metropolitan area, JR lines run parallel with lines of other private rail companies, giving rail users a choice (Nakamura and Mizutani 1995). Table 12.6 shows trends in the number of passengers and share in rails in the greater Osaka metropolitan area. From this table we can clearly see that the ridership of the JRs after privatization has increased while private rail companies have been gradually losing some of their competitiveness, so that in 1997 their share became less than 50 percent. However, the subway system operated by the local government has not been affected by the privatization of JNR, as its network does not significantly overlap with JR lines.

On 20 March 1996, a new movement was begun in Osaka: a consortium of transport organizations called "Surutto Kansai," ("Go through Kansai"), whose purpose is to increase users' convenience. Under this consortium, rail users can avoid buying separate tickets from separate railway or bus companies along their desired routes by purchasing prepaid cards that can be used on all facilities of the consortium's members. Originally there 
Trends in Number of Passengers and Share in Rails in the Greater Osaka Metropolitan Area

\begin{tabular}{|c|c|c|c|c|c|c|}
\hline & \multicolumn{3}{|c|}{ Numbers of Passengers (thousands) } & \multicolumn{3}{|c|}{ Share of Passengers ( $\%)$} \\
\hline & $\begin{array}{c}\text { JR } \\
\text { West }\end{array}$ & $\begin{array}{c}\text { Private } \\
\text { Rails }\end{array}$ & Subways & $\begin{array}{c}\text { JR } \\
\text { West }\end{array}$ & $\begin{array}{c}\text { Private } \\
\text { Rails }\end{array}$ & Subways \\
\hline 1980 & $1,086,022$ & $2,508,336$ & 813,318 & 0.246 & 0.569 & 0.185 \\
\hline 1981 & $1,079,424$ & $2,515,534$ & 986,452 & 0.236 & 0.549 & 0.215 \\
\hline 1982 & $1,059,261$ & $2,495,711$ & $1,009,021$ & 0.232 & 0.547 & 0.221 \\
\hline 1983 & $1,065,140$ & $2,515,052$ & $1,036,329$ & 0.231 & 0.545 & 0.224 \\
\hline 1984 & $1,068,560$ & $2,501,624$ & $1,046,038$ & 0.231 & 0.542 & 0.227 \\
\hline 1985 & $1,074,479$ & $2,574,773$ & 960,198 & 0.233 & 0.559 & 0.208 \\
\hline 1986 & $1,088,105$ & $2,613,680$ & 975,768 & 0.233 & 0.559 & 0.209 \\
\hline $1987^{\mathrm{a}}$ & $1,145,095$ & $2,623,316$ & 921,938 & 0.244 & 0.559 & 0.197 \\
\hline 1988 & $1,203,132$ & $2,652,969$ & $1,076,853$ & 0.244 & 0.538 & 0.218 \\
\hline 1989 & $1,197,248$ & $2,672,564$ & $1,096,877$ & 0.241 & 0.538 & 0.221 \\
\hline 1990 & $1,228,650$ & $2,715,036$ & $1,156,811$ & 0.241 & 0.532 & 0.227 \\
\hline 1991 & $1,264,666$ & $2,777,166$ & $1,167,219$ & 0.243 & 0.533 & 0.224 \\
\hline 1992 & $1,304,737$ & $2,747,929$ & $1,168,136$ & 0.250 & 0.526 & 0.224 \\
\hline 1993 & $1,367,843$ & $2,726,708$ & $1,161,090$ & 0.260 & 0.519 & 0.221 \\
\hline 1994 & $1,308,396$ & $2,885,756$ & $1,135,110$ & 0.246 & 0.541 & 0.213 \\
\hline 1995 & $1,380,645$ & $2,590,129$ & $1,157,746$ & 0.269 & 0.505 & 0.226 \\
\hline $1996^{\mathrm{b}}$ & $1,384,975$ & $2,601,995$ & $1,145,749$ & 0.270 & 0.507 & 0.223 \\
\hline 1997 & $1,379,976$ & $2,502,765$ & $1,151,611$ & 0.274 & 0.497 & 0.229 \\
\hline 1998 & $1,366,037$ & $2,439,685$ & $1,140,150$ & 0.276 & 0.493 & 0.231 \\
\hline
\end{tabular}

aPrivatization.

${ }^{\mathrm{b} C}$ Consortium.

were five member organizations, such as Hankyu and the Osaka city transport bureau. Four years later, in May 2000, twenty-six transport organizations had joined the consortium, and its network accounted for $792.1 \mathrm{~km}$ in rail lines and $2,375.2 \mathrm{~km}$ in bus routes. JR West is not specifically excluded from this consortium, but becoming a member would require the installation of ticket gate machines compatible with those of all other members, and JR West has so far opted not to undertake this installation. Whether as a result of this omission or not, an atmosphere of JR-versusthe-Others has taken hold in the Osaka metropolitan area.

The advantages of joining the consortium are as follows. First, an increase in ridership is expected due to expansion of network. Second, investment costs for system development such as for ticket gate machines can be avoided because the system is developed jointly. Third, advertising of the joint network can be expected without loss of management freedom in each organization. An advantage for users is the convenience of not having to buy tickets when changing modes of transportation. The consortium can also be judged to be good for society in that it protects the environment 
by encouraging the use of public transportation over private cars. According to the administrative office of the consortium, the number of prepaid users has been steadily increasing but a clear effect is not yet evident.

\subsubsection{Local Services}

Previously, we showed performance results in a profitable market. In this section, we will explain results occurring in an unprofitable market. Before the privatization of JNR, there was considerable debate about whether local rail services in small communities would remain intact. The concern was that newly privatized rail companies would ruthlessly eliminate any unprofitable lines, leaving the transportation-poor, such as children, the elderly, and the handicapped, to fend for themselves. Quite recently, an empirical investigation of this issue was undertaken by Mizutani (1999a).

The methodology is as follows. First, Mizutani selected local rail lines of six passenger JRs. Second, by using timetables, he obtained several service quality measures in both the first year of privatization (1987) and the tenth year after privatization (1997). He then compared these service quality measures for the two time periods. As observations, he chose a total of thirty-five lines from six passenger JRs by considering regional differences and service quality measures such as (1) departure time of the first train, (2) departure time of the last train, (3) operating time per given section of rail line, (4) number of trains per day, (5) number of trains per off-peak hour, and (6) travel time in a given $30 \mathrm{~km}$.

Mizutani's conclusion is that, overall, local rail service in small communities has been maintained since privatization, negating the fear of those who predicted that privatization would damage or even eliminate local rail service. To a certain extent, it is not surprising that local lines have fared so well, considering the financial health of the JRs since privatization. Even the three-islands JRs, which have been less fortunate financially, have managed to maintain their local lines.

However, if the financial situation takes a turn for the worse, the concern remains that the rail companies may at some point choose to abandon service, even though they have so far chosen to keep unprofitable lines despite there being no legal obligation to do so. Quite recently, however, JR West has sent out signals that it is becoming more difficult to maintain several local lines in small communities, and recent drastic reductions in off-peak services found on timetables from April 2001 augur that some sacrifices can be expected in the near future. The deficits of some local lines are being covered by cross-subsidies derived from the JRs' profitable transport operations in major urban areas. Local rail services will be abolished or converted to bus services if the JRs cannot make enough profits from major urban lines or efficiently use internal resources such as employees. According to Sumita (2000), in the future the number of surplus personnel 
may fall to zero, making it difficult to secure sufficient personnel to operate the local lines.

\subsubsection{An International Comparison of Performance Changes}

In this section, we will compare performance changes among typical rail companies in which different kinds of railway reform have been undertaken. We selected the same organizations used earlier: the JRs, British Rail (BR), Swedish State Railways (SJ), and French National Railways (SNCF). Table 12.7 gives a summary of performance changes. In this table, the reform of SNCF, in which the French Railway Network (RFF) was established, was accomplished in 1997, so that these numbers are all representative of SNCF. The privatization of BR occurred in 1993, so that the numbers for BR in 1995 are the combined numbers of TOCs and Railtrack. Rail reform in Sweden took place in 1988, so that numbers since 1989 are the combined numbers of SJ and Banverket (BV). Finally, JNR's privatization began in 1987, so that the numbers since 1987 are the total numbers from the seven JR companies. These statistics have been calculated by the authors based on the original from the International Union of Railways.

This table shows, first, that railway reforms commonly lead to an increase in labor productivity, and have certainly done so in the United Kingdom, Sweden, and Japan. The growth ratio of labor productivity of reformed railways is higher than that of nonreformed railways. For example, the growth percentage between 1987 and 1995 for SNCF was 1.179 but was 1.668 for BR, 1.598 for SJ, and 1.255 for the JRs. Labor productivity growth was accomplished mainly through the reduction of employees.

The second benefit of rail reform is the subsequent increase in rail demand. For passenger transport, both the JRs and SJ increased demand between 1987 and 1995. Although the statistics for BR in this table shows a decrease, the demand for passenger transport began an upturn after 1995, according to one source (Preston and Root 1999, 52). However, reform does not seem to affect freight service, with all freight services except SJ continuing to show a decrease. According to one source (Alexandersson and Hulten 1999, 114), even SJ suffered a sharp decline in freight service after 1996: 16.5 billion tons per kilometer in 1996, 14.7 billion tons per kilometer in 1997.

On the other hand, different results were found among railways regarding the operating revenue-cost ratio, a measure that greatly increased for the JRs but that decreased for all other railways. Although both BR and SJ were reformed, this measure worsened, most likely due to an increase in operating costs, with operating costs increasing most drastically in the United Kingdom. We know that operating costs rose both for operation and infrastructure, but due to a lack of available information, we cannot give details. 


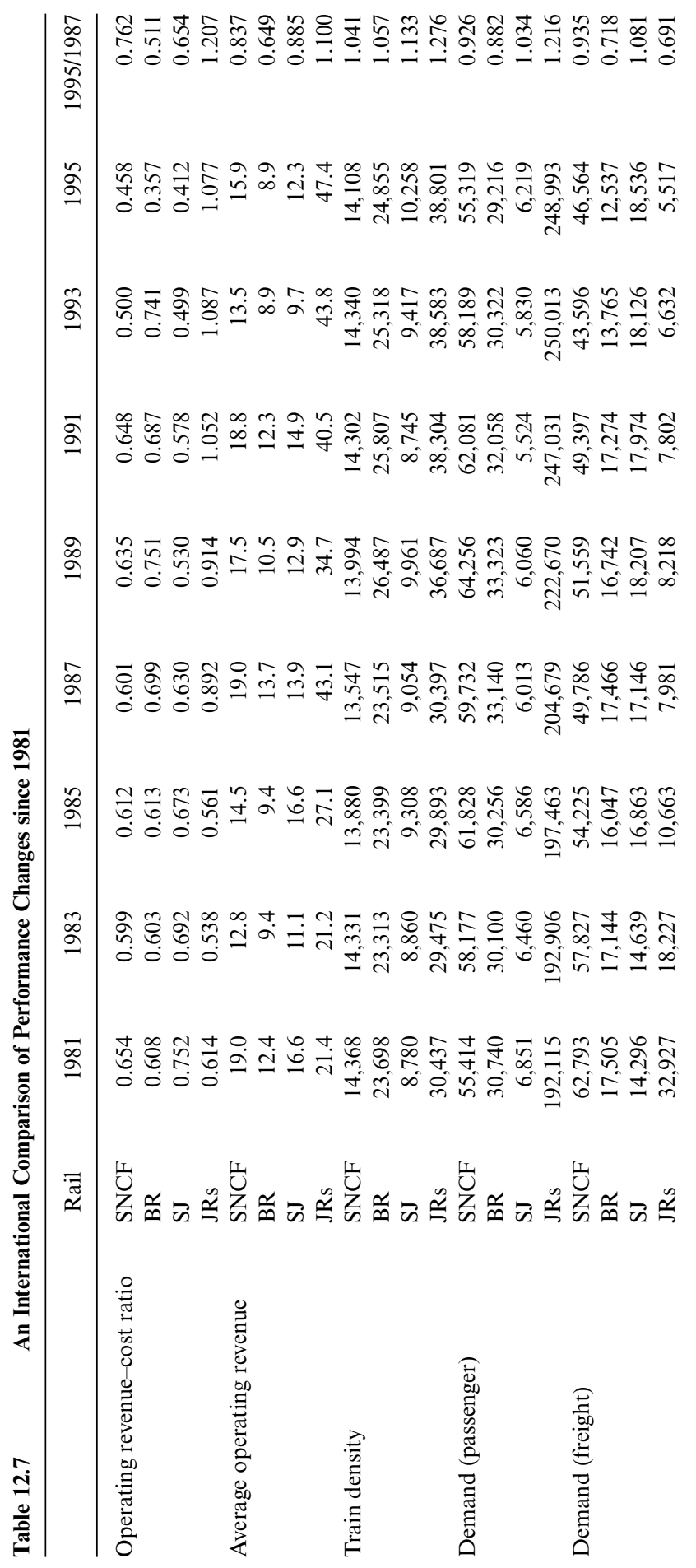




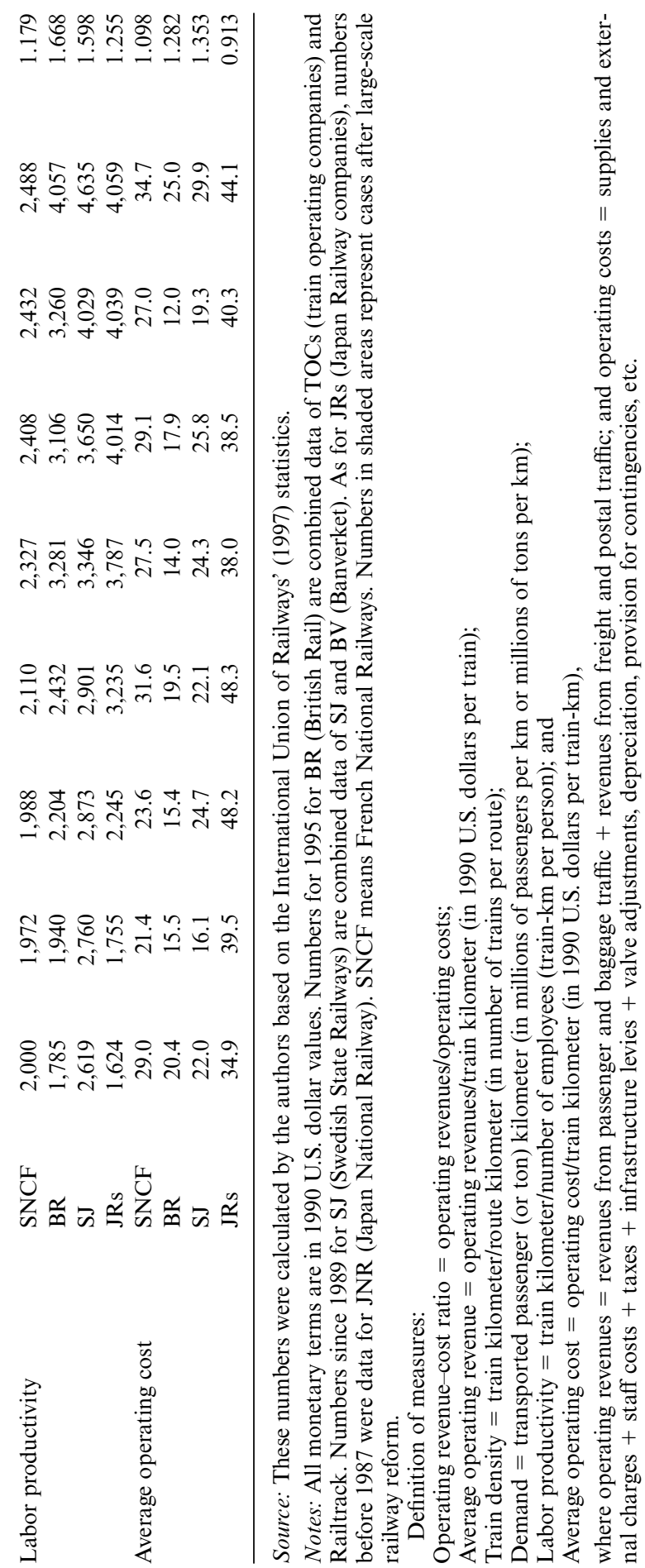


In conclusion, we regret that we cannot discern clearly from our results

what kind of railway reform works best in every case. Part of our inability to do so is the consequence of a lack of available data. We hope that as railway-reform data accumulate, we will be able by econometric techniques to obtain results that will guide us in making wiser policy decisions in the future.

\subsection{Selected Important Lessons}

\subsubsection{Regional Subdivision: Horizontal Separation}

We believe that the policy calling for the subdivision of the nationwide Japanese railway system was correct. The issues are how the system should be divided and how big each organization should be. As for the first question, while other alternatives for dividing the JNR were discussed both officially and unofficially, regional subdivision was selected. At least three other possible options were discussed: four regional subdivisions based on the four main islands (Honshu, Hokkaido, Shikoku, and Kyushu); about twenty regional subdivisions based upon the branch offices of JNR; and division into trunk lines and branch lines. The last two were rejected, first, because there was great financial variation among the twenty subdivisions due to differing rail demand conditions, and second, because branch lines could not be financially independent. As for the proposed four subdivisions, the Honshu region was considered to be too large compared with the other three, thus needing further subdivision. In addition to these three alternatives, a division into urban rail operation and intercity rail operation was suggested, but was rejected as not feasible technically because both operations use the same tracks.

Regional subdivision of the passenger rail service seems to be functioning well so far. First, yardstick competition has improved the overall performance of the JRs. Second, more regional needs have been met, particularly with improvements in frequency. Third, as for the integration of railway services into different regional organizations, not many problems have been reported, although the number of interregional rail services has decreased.

As for the second issue, six regional passenger companies were created. One problem in Japan is the wide variation in the size of the six regional passenger rail organizations, reflecting demand and transportation density. The Honshu JRs (JR East, JR Central, and JR West) are in a highly advantageous position compared with the three-islands JRs (JR Hokkaido, JR Shikoku, and JR Kyushu). As for the size of organization in terms of cost, there is a problem. According to Preston (1996), the optimal railway size for minimizing operating costs might have a network of around 4,000 km and run 120 million train-km per annum. His pioneering 
results provide useful information for the restructuring of the rail industry but, for us, have the limitation of having been obtained from European state railways. It is necessary to get more precise information about privately owned railways.

Research on the optimal size of rail organizations has recently been done by Mizutani (2001), who estimated the total cost function for pooling data of fifty-nine privately owned urban railways for every five years from 1970 to 1995 in Japan. He calculated the railway size to attain the minimum average cost in terms of service output and network size. That is, he obtained the size by differentiating the average cost function by three measures: service output, number of lines, and average line length. He found the optimal size, which attains the minimum average cost, to be about 128 million vehicle-km per year with a network of $15.0 \mathrm{~km}$ per line, and with five lines. In this case, the average costs are 418.8 yen per vehicle- $\mathrm{km}$. The optimal size in terms of output is found to be smaller than Preston's (1996) result, which shows that the optimal size in terms of train-km is 120 million. When we translate Mizutani's result of output to train- $\mathrm{km}$, the result would be about 43 million train- $\mathrm{km}$ (= 128 million vehicle-km / 3 cars per train). Furthermore, in terms of network size, Mizutani's result is much smaller than Preston's because the total length is about $75 \mathrm{~km}(=15.0 \mathrm{~km}$ per line $\times 5$ lines). Presumably, Mizutani's data set is based on urban rail organizations so that the network size would be smaller. In other words, Japanese railway systems are more densely operated than those in other countries.

Based on Mizutani's result, we evaluate the size of the railway organization. His result shows that large private railways, which are considered the most efficient rail operators in Japan, could be approximating optimally sized railways. The Odakyu line operating in Tokyo might be an optimally sized railway operating under ideal conditions. If Mizutani's result is correct, JR Shikoku is perhaps too small and the Honshu JR companies too big in terms of costs.

\subsubsection{Functional Division: Passenger and Freight Services}

We think that functional division was correct for Japan, where railways are mostly for passenger transport. Freight transport is by either truck or ship, with rail holding only a 4.2 percent share on a ton-kilometer basis. Clearly, before privatization, the freight section of JNR was unprofitable, unable to compete with trucking companies and deficient in marketing skill. In fact, JNR's freight division was one of the main sources of JNR's operating deficits. If such an unprofitable establishment had been attached to any of the JR passenger companies, their prospects for success would have been reduced, and their listing on the stock market would have been less favorable.

We might also cite the argument of scope economies in order to ration- 
alize the separation of passenger and freight service. Several researchers have noted that there are diseconomies of scope with passenger and freight operations in the railway industry (Kim 1987; Preston 1996). From this point of view, it is not necessary to provide both passenger and freight services under the same train company. Instead, the consolidation of freight rail companies with trucking companies may be preferable.

\subsubsection{Operation and Infrastructure Integration: Vertical Integration}

The issue of vertical integration still stimulates much debate in the rail industry. The relationship between operation and railway infrastructure can take many forms (Brooks and Button 1995). In the European style, for example in the case of the BR privatization, rail operation was separated from infrastructure. In Japan, JR passenger companies hold rail tracks, as most other Japanese private railways do, and cases involving only operation or only ownership of infrastructure are very limited, with Kobe Kosoku and JR Freight being examples of the few.

Empirical results are insufficient to allow a policy judgment on this issue, as a concrete theory has yet to be developed in the rail industry. However, transport economists have discussed advantages and disadvantages, as did the British economist Nash (1997), who wrote of the BR experience. Vertical separation makes it easier to (1) promote a variety of operators, (2) clarify intra-industry relationships, and (3) specialize activities. On the other hand, vertical separation makes it difficult to (1) set up fair prices and monitor performance, (2) organize time-tabling and slot allocation of trains, (3) negotiate arrangements for investment projects, (4) maintain safety of train operation, and (5) provide integrated information and ticketing.

There are two important factors that make a vertically separated system undesirable in Japan. The first factor concerns transaction costs, and the second is the existence of economies of scope between operation and infrastructure providing services. Although we do not have clear evidence, vertical integration or a separation policy is related to these two factors, which may depend on traffic density. For example, under the condition of low traffic density, the integrated system is not efficient because the fixed cost of track maintenance is too high and the rail company could save money by outsourcing with a construction company. Transaction costs related to separation are not significantly large because the traffic is not so heavy that transactions between two companies could not be conducted on an ordinary basis. On the other hand, as traffic density increases, scope economies between the two activities come into play so that the company has an incentive to carry out the two activities. At least, it may be said that there are diseconomies of scale when the two activities are separated. Furthermore, transaction costs related to separation become larger. As many transport economists point out, in the scheduling of track maintenance 
under heavy operation, and with regard to investment plans for signals and tracks that affect train operation, cost allocation between the two activities will be a considerable issue between the two companies. As a result, transaction costs related to these will increase, such as the opportunity cost of meeting-time, the legal costs of reaching agreements, and the costs of reducing asymmetric information. All these costs make a vertically integrated system seem desirable.

Cost efficiency does not exist in vertical separation in the rail industry. Mizutani and Shoji (2001) attempt to evaluate this subject with a limited data set. Their methodology is straightforward. First, they construct the cost function for track maintenance activities by using a vertically integrated system. Second, they substitute the data of a vertically separated organization, in this case the Kobe Kosoku railway, into the estimated cost function and obtain the infrastructure cost. Finally, they compare these estimated infrastructure costs, which are considered as a case of a vertically integrated system with the actual costs of a vertically separated system. They find that the vertically separated system costs about 5.6 percent more than the vertically integrated system, and thus conclude that there are no significant cost differences between the two systems. This is a just case based on reported accounting costs of railway firms; opportunity costs of transactions, especially time costs of meeting, negotiation, and search, are not included. If we consider these costs, a separated system might be more expensive than an integrated system.

In summary, in the case of low traffic density, a vertically separated system is cheaper than a vertically integrated system but in the case of higher traffic density, the integrated system may be better. The policy option for vertical separation was not considered at all when JNR was privatized (Suga 1997), because when compared with European railways, the much higher traffic volume of the JRs makes it less likely to succeed with a separated system.

\subsubsection{Yardstick Competition}

A yardstick competition scheme is used for avoiding inefficiency resulting from a too-lenient licensing system. Compared with an open-access system, in which operators are selected by tendering, a yardstick competition scheme is less rigorous but still encourages competition. Shleifer (1985) originally proposed the conceptual framework of yardstick competition, which is considered competition among companies in different markets. The essence of the scheme is for regulators to evaluate companies' performance with selected performance measures. For example, a regulator sets up several performance measures, such as operating costs or productivity, and evaluates companies' performance. If a company can be shown to perform relatively better than other companies in these measures, then the company may receive rewards (e.g., their proposal for increased fares 
can be accepted). On the other hand, a company that performs less well might be penalized by having its requested fare increase rejected. Thus, this scheme is a kind of incentive regulation in order to improve companies' efficiency by introducing competition. In Japan, yardstick competition has been used since the mid-1970s in reviewing proposals for fare revision among fifteen large private railways. The evaluation measures considered in Japan are productivity growth, cost reduction, and improvement of rail ridership, and if these measures cannot be shown to equal or surpass those of other rail companies, then changes in rail fare are not fully granted by the regulator. While yardstick competition has been used for more than two decades for evaluating large private railways, it has been used at the JRs only since 1997, and cannot yet be shown to have clear effects. Competition certainly works to some degree in the large private railways to which the yardstick competition scheme applies (Mizutani 1997).

In the long run, a licensing system incorporating yardstick competition may attain more efficiency. Long-term commitment to a line is also important. Private rail companies in Japan have traditionally shown this commitment by developing real estate and shopping establishments along rail lines. A company involved only in rail operations might not share this longterm commitment, in the uncertainty that it may lose its operating license at some point. It is conceivable that an operations-only company, with its attention focused only on fulfilling the minimal promises of a written contract, might lose the entrepreneurial behavior characteristic of a major private rail company. Service quality might therefore suffer, ultimately leading to a change in the location of households and further decline in rail business.

In conclusion, a yardstick competition scheme seems a useful part of the licensing system in the long run. So far, the larger private rail companies in Japan that operate within the yardstick scheme have performed well, demonstrating a commitment to the development of a pleasant housing environment along their lines and quality rail service on their trains.

\subsection{Concluding Remarks}

In conclusion, the Japanese approach to rail restructuring has succeeded in many ways, by improving productivity, cutting operating deficits, decreasing fares, and providing better services. Although political intervention after privatization has lessened, JR companies are not yet totally independent because the privatization process is not yet complete. Local rail services in small communities have been maintained for the past ten years but there are no guarantees that these will survive any serious financial slump the JRs might someday experience.

While the Japanese privatization has been largely a success, there remain a number of problems to be solved in the near future. Care must be taken 
that privatization should not result in a simple transfer of monopolistic power from a public corporation to the private sector. The main objective of privatization policy is to introduce many kinds of competition, and it is the government's role to create a competitive environment and to promote actual and potential competition in the market and even within the organization itself by using incentive regulations. Furthermore, in Japan the older and very successful large private railways have served as good role models for the newly privatized JRs. The former national railway was conservative, indolent, and fearful of change. The privatization process has served to rouse it from its former, rather inert state into something much more purposeful.

\section{References}

Alexandersson, G., and S. Hulten. 1999. Changing trains: Sweden. In Changing trains, ed. D. M. van de Velde, 79-141. Aldershot, U.K.: Ashgate.

Brooks, M., and K. Button. 1995. Separating transport track from operations: A typology of international experiences. International Journal of Transport Economics 22 (3): 235-260.

Europe Conference of Ministers of Transport (ECMT). 1998. Rail restructuring in Europe. Paris: Organization for Economic Cooperation and Development.

International Union of Railways. 1997. Chronological railway statistics 1970-1995. Paris: Statistics Centre of the International Union of Railways.

Ishii, Y., K. Okada, and T. Yada. 1994. Henkakuki no tetsudo keiei: Kyushu Ryokyaku Tetsudo Kabushiki Kaisya (Railway management in the age of changes: Kyushu Railway Company). Unyu to Keizai 54 (4): 5-40.

Kim, H. Y. 1987. Economies of scale and scope in multiproduct firms: Evidence from U.S. railroads. Applied Economics 19 (6): 733-741.

Kitani, S. 1997. JR Nishinihon ni okeru mineika no shinten to sono kouka (Privatization progress and its effects at JR West). In Mineika no Kouka to Genjitsu, ed. T. Imamura, 261-287. Tokyo: Chuo Hoki.

Ministry of Transport, Railway Bureau, ed. 2000. Suji de miru tetsudo 2000 (Rail fact book 2000). Tokyo: Transportation Policy Research Center.

Ministry of Transport, Regional Transport Bureau, ed. 1986. Suji de miru tetsudo 1986 (Rail fact book 1986). Tokyo: Transportation Policy Research Center.

Mizutani, F. 1994. Japanese urban railways: A private-public comparison. Aldershot, U.K.: Avebury.

- 1997. Empirical analysis of yardstick competition in Japanese rail industry. International Journal of Transport Economics 24 (3): 367-392.

. 1999a. An assessment of the Japan National Railway companies since privatization: Performance, local rail service, and debts. Transport Reviews 19 (2): $117-139$.

1999b. Changing trains: Japan. In Changing trains, ed. D. M. van de Velde, 255-306. Aldershot, U.K.: Ashgate.

2001. Privately owned railways' total cost function, organization size, and ownership. Kobe University, Graduate School of Business Administration. Mimeograph (revised version). 
Mizutani, F., and K. Nakamura. 1996. Effects of Japan National Railways' privatization on labor productivity. Papers in Regional Science 75 (2): 177-199. 1997. Privatization of the Japan National Railway: Overview of performance changes. International Journal of Transport Economics 24 (1): 75-99. 2000. Japan railways since privatisation. In Privatization and deregulation of transport, ed. B. Bradshaw and H. Lawton Smith, 205-235. Basingstoke, U.K.: Macmillan.

Mizutani, F., and K. Shoji. 2001. Operation-infrastructure separation in Japanese rail industry: The case of Kobe Kosoku Tetsudo. Paper prepared for the World Conference on Transport Research. 22-27 July, Seoul, Korea.

Moyer, N. E., and L. S. Thompson. 1992. Options for reshaping the railway. Policy Research Working Paper no. 926. Washington, D.C.: World Bank, June.

Nakamura, K., and F. Mizutani. 1995. The effects of railway privatization on competitive performance: A case study of Japanese railways. Journal of the Eastern Asia Society for Transportation Studies 1 (1): 85-102.

Nash, M. C. A. 1997. The separation of operations from infrastructure in the provision of railway services: The British experience. In The separation of operations from infrastructure in the provision of railway services, ed. European Conference of Ministers of Transport (ECMT), 53-89. Paris: Organization for Economic Cooperation and Development.

Preston, J. 1996. The economics of British rail privatization: An assessment. Transport Reviews 16 (1): 1-21.

Preston, J., and A. Root. 1999. Changing trains: Great Britain. In Changing trains, ed. D. M. van de Velde, 5-78. Aldershot, U.K.: Ashgate.

Shleifer, A. 1985. A theory of yardstick competition. Rand Journal of Economics 16 (3): 319-327.

Suga, T. 1997. The separation of operations from infrastructure in the provision of railway services: Examples in Japan. In The separation of operations from infrastructure in the provision of railway services, ed. European Conference of Ministers of Transport (ECMT), 153-176. Paris: Organization for Economic Cooperation and Development.

Sumita, S. 2000. Success story: The privatisation of Japanese national railways. London: Profile Books.

Van de Velde, D., and P. van Reeven. 1999. Changing trains: Synthesis and general lessons. In Changing trains, ed. D. M. van de Velde, 345-364. Aldershot, U.K.: Ashgate.

\section{Comment Mario B. Lamberte}

This paper discusses the most recent experience of Japan in restructuring and privatizing a rather large and important utility, the Japan Railway. The privatization is still unfinished, yet some lessons already can be drawn from the experience. What I gathered from the paper is that Japan made a very careful plan for and then execution of privatization. For example, JNR was divided into six regional companies (JRs): each one would complete 95

Mario B. Lamberte is president of the Philippine Institute for Development Studies. 
percent of all trips within the borders of the region, and there was to be one nationwide freight company. The privatization of each of these companies was done sequentially. The timing of the privatization was as important as the sequence. Rather than copying in toto the railway privatization program implemented in other advanced economies, the Japanese government took a slightly different route that was most suited to Japan's conditions. For instance, it opted for vertical integration instead of vertical separation, allowing the JRs to reduce transaction costs and exploit economies of scope between operation and infrastructure. More importantly, the privatization immediately yielded some benefits to the Japanese society and minimized social costs.

In describing the reasons for privatization, it would help the readers if the authors had started with a discussion about the market structure of the railway industry. I gathered from certain sections of the paper that JNR was facing competition not only from motorization but also from the existence of relatively efficient private railway companies. Do each of the JRs operating in their respective geographical areas face fierce competition with private companies? The presence of vertically integrated private railway companies could have also been a major consideration in opting for vertical integration.

In developing economies, like the Philippines, the railway industry usually is monopolized by state-owned enterprises. Privatization results in a transfer of monopoly power from the government to the private company. Regulation and supervision therefore must be strong. Unfortunately, regulatory capture occurs most of the time. Therefore, this makes the experience of Japan even more interesting, because private companies were allowed to operate in the railway industry even before the privatization of JNR. I am very interested in the legal and regulatory framework that Japan put in place to allow those private railway companies to operate. This could be an alternative route that less developed countries could use when they privatize their railroad companies.

One of the interesting features of the JNR privatization was the setting up of an intermediate institution to repay the debts of JNR and to find new jobs for redundant employees. That feature would make the privatization of JNR acceptable to those who would be adversely affected in terms of employment. However, it is not clear to me what programs the intermediary institution undertook to make the transfer to other government agencies smooth. Were there pressures exerted by the central government on other government agencies to accept the redundant workers of JNR? It could be difficult to transfer redundant workers from JNR to other government agencies, unless these government agencies also are growing and therefore need some additional labor.

Table 12.3 shows the overall performance changes of the JRs since privatization. My understanding is that only JR East, JR West, and JR Cen- 
tral have been privatized so far. It might help if the authors compared the performance of those JRs that already have been privatized with those that have not yet been privatized. More importantly, they should describe the difference in governance structure in these two groups of JRs. They should also describe the extent to which the government formally or informally controls the three privatized JRs, since it still holds at least 30 percent of the total shares outstanding.

In table 12.4, the authors show a comparison of the fares between the JRs and private companies before and after the privatization. Although there seems to be improvement in the price competitiveness of the JRs, we still notice significant differences. Theoretically, the fares of JRs and private companies should converge unless the former have retained some monopoly power. Perhaps the authors can expand more on this issue and speculate when these fares will become approximately the same. It would certainly help the reader if the authors gave an idea of the market shares of the JRs and the private railway companies in the same market.

The privatization plan and sequencing outlined in table 12.1 is something that a country planning to privatize its railway industry must learn. The downloading of fare-setting from the Diet to the regulatory agency certainly depoliticized the process. I wonder if there is a fair and transparent process followed by the regulatory agency in revising rates, because the process itself still could be highly politicized.

Some of the questions that the authors should have answered, which surely will be of interest to those who are looking seriously at the JNR experience as a model, are the following:

1. How is the board of the JRs organized?

2. When should the remaining JRs be privatized? Should the government wait until Japan's stock market recovers?

3. What would be the additional costs to be borne by the government by retaining some JRs?

\section{Comment Helen Owens}

The Mizutani and Nakamura paper provides a clear summary of recent reform initiatives relating to Japanese railways. On many issues it represents a convergence of ideas with those of the Australian Productivity Commission (PC), which were formed while undertaking a major review of Australian railways two years ago (PC 1999). 
I would like to provide comment on three general matters.

The first is the Japanese approach to rail reform, which has included both structural reform and partial privatization of some railways. There would appear to be a strong case for the horizontal separation, by region, of JNR, which appears to have experienced similar problems to those of other large, publicly owned corporations worldwide. These include complacency, poor management, antagonistic labor relations, overstaffing, huge debts, low morale, political interference, and diseconomies of scale. These problems tend to result in an increased dependence on government subsidies, reduced productivity, poor-quality services, and a reduced ability to compete on an intermodal basis with road and air services.

Horizontal separation holds the promise that rail service providers will be better able to meet different local needs. It can facilitate organizational changes and yardstick competition across businesses. It can also improve the effectiveness of government regulatory regimes and enable government to design contractual arrangements to meet noncommercial objectives (social, regional, and environmental).

On the downside, there may be issues relating to lack of coordination between geographically separated entities and interface issues where the freight operator traverses different passenger networks with multiple owners. On balance, the benefits of horizontal separation by region are likely to far outweigh the costs.

In regard to horizontal separation by product (or function), I would tend to agree with the authors that there are strong arguments for separating passenger from freight operations in Japan. This will ensure management has clear responsibility and that privatization of the more profitable passenger businesses is not undermined by loss-making freight operations. Potentially, the needs of different types of users (passengers, freight forwarders) can be met more effectively. Also, to the extent that the freight company traverses different passenger networks, it would not make sense to link it to one passenger railway.

The authors also cite evidence of diseconomies of scope. Recent experience in New Zealand with the horizontally and vertically integrated, privately owned TranzRail suggests that retaining loss-making urban and long-distance passenger services within a privatized entity can undermine its overall operations, despite regional government subsidies. In 2001 TranzRail repositioned itself as mainly a bulk freight operator, having sold the long-distance passenger service operating between Auckland and Wellington (an intercity commuter operation) as well as two profitable tourist train services on the South Island.

Once again, I agree with the authors that vertical integration of track and operations is the appropriate approach in the Japanese context.

There are a number of possible advantages to vertically separating train operations from track infrastructure services. According to the Organiza- 
tion for Economic Cooperation and Development (1999), economic efficiency can be enhanced by introducing rail on rail competition through vertical separation when

- existing rail operators possess natural monopoly characteristics such as economies of scale and have effective market power;

- other operators can compete on a commercially sustainable basis; and

- track infrastructure and train operations are relatively independent so that the costs of separation are small in relation to the gains from competition and efficient economic regulation.

However, despite the relatively large size of some Japanese passenger markets, market power may not eventuate given the degree of intermodal competition. Thus the opportunities for competitive entry could be limited.

Other problems with vertical separation (and subsequent greater railon-rail competition) noted by the authors include the difficulties of monitoring performance; organizing time-tabling and slot allocation; maintaining safety (as evident in United Kingdom); and undertaking long-term investment planning.

In addition, the authors noted that the potential for adversarial relationships to develop between the track owner and operating companies (as manifested in the United Kingdom) may be a problem. In the case of the three Japanese Honshu companies operating high-density services, it is especially important to avoid complications associated with train schedule allocation, time-tabling, and capacity management.

The authors argued that vertical separation may be more appropriate under conditions of low traffic density. However, to the extent that rail businesses encounter high fixed costs associated with inefficient track maintenance, these could be more easily reduced by outsourcing maintenance while maintaining ownership and control. This approach also would avoid any transactions costs of changing ownership.

On balance, the PC review concluded that the benefits and costs of structural separation are likely to differ between network types. It would appear that, in the case of Japan, the characteristics of its transport market would suggest the approach adopted to structural reform is largely appropriate.

The problems encountered by JNR also strongly suggest that privatization or other measures to introduce greater private-sector involvement are appropriate. However, I have some concerns about the privatization process. To date, only three of the seven companies formed from JNR have been partially privatized and the process has been very slow. Six years elapsed from the initial announcement in 1987 until the first partial privatization of JR East in 1993. The partial privatization of JR West and JR Central followed in 1996 and 1997, respectively. The decision to privatize slowly appears to be aimed at giving the companies more time to become 
more efficient and show a profit in order to increase the sale price and hence government revenue. However, it is unclear why private purchasers would not recognize the potential for future efficiency gains and factor them into the purchase price.

An alternative approach adopted in other countries would be to privatize the businesses as going concerns in order to promote faster efficiency gains, with ongoing community benefits from lower prices probably exceeding any forgone budget revenue.

The danger with the Japanese strategy is that other forces, such as recession or political changes, could cause the process to lose momentum or stall altogether, as appears to be the case. The opportunity for more efficient operations is therefore lost.

Another concern relates to the strategy to privatize the three Honshu rail companies only partially. Again, a danger exists that tensions may arise between the government and private shareholders, as well as that of ongoing political interference in the companies that could restrict organizational and managerial flexibility.

Finally, the authors mention that in privatizing the three Honshu companies, jobs were found for redundant employees with other government agencies, including local governments, the tax office, the police, and the meteorological bureau. If one were to take a whole-government perspective, this may simply shift the inefficiency from one government agency to others.

The second matter on which I would like to comment is the performance of Japanese railways presented in table 12.2 of the paper. It is hard to disentangle the impact of structural reform from privatization as the two processes overlap. Only the data for 1998 relate to the period since privatization of the three Honshu companies (in 1993, 1996, and 1997), so there are insufficient data points to be definitive about the effect of privatization. Further, one year is insufficient time to gauge the impact of the privatization of JR Central. Nevertheless, the data are starting to tell an interesting story.

For the three privatized companies,

- the operating revenue-cost ratio increased between 1987 and 1992 but fell again in 1998 after privatization (this may be due in part to recession);

- average fares fell consistently for JR East and JR West, but rose slightly for JR Central in 1998 (although they were still marginally lower than in 1987); and

- labor productivity rose consistently for JR East and JR West, but increased and then fell for JR Central (although they were still higher than in 1987).

However, labor productivity also rose significantly for the four nonprivatized companies, possibly reflecting the impact of structural reform. The 
operating revenue-cost ratio also rose for the other passenger companies, but fell for JR Freight. Average operating costs were lower in 1998 than 1987 for all passenger companies but rose for JR Freight. From these results it would appear that any improvements in performance are likely to relate more to structural reform than privatization per se.

My third point is that franchising is an alternative approach to reform that could have been considered. It is clear from the paper that the publicly owned Three-Islands passenger companies are still operating at a loss, as is JR Freight, possibly explaining why they are yet to be privatized under the policy of waiting until they become profitable. This may take a long time, given the slow improvements to date.

Another approach that could be considered for the Three-Islands companies would be to promote "competition for the market" by entering into franchise agreements or contracts with the private sector. To the extent that these services are noncommercial and require continued government support, private companies could tender competitively to operate the service at the lowest subsidy. Investment, quality, and other performance requirements could be incorporated into franchise agreements (or contracts). This would overcome the concerns of the authors with such an approach.

This approach was adopted in the Australian state of Victoria in 1999 for all urban and nonurban passenger services. The urban passenger operations were split into two companies and franchised to separate private companies, one of which also operates the nonurban passenger service. The franchisees lease the track infrastructure. The franchise agreements, which were originally designed to run for ten to fifteen years, specify passenger service levels, maximum fares, and operational performance. Investment commitments are also specified in the contracts, along with subsidy payments.

An approach involving "competition for the market" could be considered for loss-making railways.

\section{References}

Organization for Economic Cooperation and Development. 1999. Competition and railways. Journal of Competition Law and Policy 1 (1): 149-228.

Productivity Commission (PC). 1999. Progress in rail reform. Inquiry Report no. 6. Canberra, Productivity Commission, August. 